But I will not correspond publicly with any mere individual on this matter. My appeal was to the committee. Noanswer has appeared from them, and $\mathrm{Mr}$. Thomas Partridge's letter is not their's, nor are they cesponsible for its statements. It is the committee who by their advertisements produced the public impression that the family were wanting the common necessaries of life, and if they do not publicly justify such statement when thus questioned by an impartial observer, the public will infer they cannot. Not that I snggest intentional misrepresentation to those gentlemen; for I am led to believe that many of them neither attended the meeting nor knew the facts, but gave their names and money from pure benerolence. One highly respected M.D. of Birmingham gives me some curious information on this point.

Through the information I receive from various Birmingham sources, medical and otherwise, I am inclined to predicate that the committee will not deny the following as a close approximation to the truth; and, if it should be necessary to publish the evidence on which the statements are given, any presumed private inconvenience that may result from it to the purchaser of the practice (which $I$ shouid much regret) must rest with those wo would try to perpetuate an erroneous impression.

1. That when the objec ionable advertisements (addressed to the public, not to the profession only) were issuing, the total family resources alone, without the subscription list, and without any pecuniary aid from relatives or friends, amounted in money to several hundreds more than $£ 2000$; and proved that in income (for several years at least) there would be upwa:ds of $£ 140$ a year, besiles the chance of some $£ 30$ a year fur her improvement of income by different investment of the $£ 1500$ settlement now in the funds.

2. That before the publication of Mr. Thomas Partridge's letter some $£ 80$ or $\mathfrak{E 9 0}$ in muney from relatives and attached friends alone was given or promised to the widow and children, or in the subscription list; and that there was a sals of horses \&c. by the willow, yielding from $£ 50$ to $£ 70$.

3. That the widow has a bachelor brother in very good circumstances (and she is his nearest living relative), who never \$as consulted as to such a public appeal.

I should have supposed that die courtesy to a large circle of connexions would alone have militated against the putting forth of such advertisements by any committee under the circumstances; and it appears to me thus far almost demonstrated that there could be no want of the necessaries of life. Surely any family in the condition under consideration, as regards friends, \&c., could obtain credit for a few months, assuming for the sake of argument the absence of any ready money whatever. While Mr. I'homas Partridge adopts one son, there are rumoured promises of elucation and placing out in the world of another son and a daughter by relations or friends.

I am told by a respected medival correspondent that there is a " strong feeling against the whole affarr amongst many of the profession" in Birmingham, but that they naturally are afraid of incurring odium or of having their motives impugned by protesting publicly. This gentleman adds that $\mathrm{Mr}$. W. W. Partridge before his bankruptcy, being very partial to field sports, rented the shooting \&c. of a manor or estate; that "he lived in a stylish and expensive manner, kept a close carriage and pair, ponies for his children," \&c. ; while another - says that at his death he kept eight or ten dogs and several horses.

Having performed an unpleasant duty, I now beg to enclose $m y$ cheque for $£ 5$ to add to the fund, and request the bereaved family to accept this donation at least, not in form $a$ pauperis, but as a recoguition of the generous and open-handel (though somewhat jmprovident) chiracter of the departed, and their own slender provision.

I am, Sir, your obedient servant,

Gore Lodge, Hyde-park, Mureh, 1864. S. B. BrRch, M.D.

P.S. - I have just heard from another correspondent that the brother of the widow han the kind of appeal fully stated to him by some of the committee before it was published. To the exteut of this rather singular fact (if true) I am glad to modify my communication.

\section{ZLECTION OF SURGEONS TO THE LEEDS INFIRMARY.}

To the Editor of THE LANCET.

ErR, - The farce of an "election" of three surgeons to the Leeds Infirmary (rehearsed several weeks ago) was performed an the 28 th inst. In justice to ourselves we have to explain that, agreeably to a suggestion which appeared in The LaNCer of 27 th February, the requisition, a copy of which accompanies this note, was issued to thirty.three of the ignored general practitioners of Leeds. From apathy in many, under the knowledge of having been shamefully forestalled, and timid reluctance in others to appear openly against the "clique," althou all who are at hberty to speak condemn the jobbery in private, only two of the invited attended the meeting ! Those two, however, came not to approve, but the reverse, one having passed much of his early career as boy and youth in the Leeds Dispensary, the other, a son of a gentleman for many years resident medical officer to the same institution. and to which Mr. Wheelhouse, one of the three newly elected of the Intirmary, is surgeon. Besides these, two inrividuals intruded themselves - viz., the present resident medical officer of said Leeds Dispensary, and the resident medical officer of the House of Recovery, both of whom, by the tenure of their service, are expressly debarred from general practice, and, therefore, had no right to be present. They were repeatedly desired to withdraw, but with as little of decency as correct taste, they would not. It soon became palpably evident that they had been sent fully charged to deny, contradict, and oppose every. thing, a course strikingly corroborative of the objectionable character of the entire proceedings of the so-called "election," and of their instigntor's conscionsness of this. We felt as much contempt for as disgust at the behaviour of the employes in this importinent intrusion; and these did at length think fit to withdraw themselves under a mock resolution to adjourn sine die. We then felt that as so considerable a number of our professional brethren-grossly wronged and publicly insulted equally with ourselves by the unbecoming measures of a selfish clique of the "Leeds School of Medicine"-had not the spirit to resent, or record their indignation thereat, we must rest satisfied with having done our part in the matter.

T. F. SagaR, Surgeon.

R. G. MaYne, M.D., Surgeon.

Leeds, 29th March, 1864.

J. EWAR', Surgeon.

\section{MURPHIA INJECTIONS IN NEURALGIC AFFECTIONS.}

To the Editor of THE LANomT.

SrR, - T have read with interest the remarks (in THE LANCET of the 12th March) of Dr. Benuet on the value of morphia in. jections for the relief of neuralgic pain; and I may say that in several cases I have found marked benefit from this remedy, more especially in the treatment of sciatica. In no less than three cases where every other remedy had been tried, and where the patient was reduced to almost a skeleton through the suffering incidental to the malady, immediate relief was derived from the morphis injection. In one case, that of a medical man, the success of the treatment was very great: in the height of suffering and nervous irritation, immediately upon the use of the remedy relief was experienced, the whole system was lulled and calmed, and the sufferer dropped into a quiet sleep, free from the slightest pain.

Snch having been my experience of this remedy in nerrous affections of the lower extremity, I naturally infer that equally satisfactory results would follow its application in other nervous affections of the body; and I sincerely hope to find the use of this remedy become more general in the treatment of neuralgic affections. The relief of the suftering is immediate, and in some cases lasting. It would be very satisfactory if those gentlemen who have had experience in the use of this remedy would give their opinion as to its value. The operation is very simple, and attended with no pain; but I have had patients wholooked upon it with dread, through not being aware of its very simple nature. - I remain, Sir, yours respectfully,

Chandos-street, Cavendish-square, March, 1864. Joun Harvey, M.D.

\section{A DEBT OF HONOUR. To the Editor of THE LANCET.}

Srk,-Will you allow me space for a report of the amount already received by me as treasurer of the fund for liquidating the debts incurred by the National Medical Registration Association in their strenuous exertions to advance the welfare of the profession. The columns of THE LANCET have from time to time borne testimony to the value of the work thus done. Up to the year 1861 the Association zealously continued its 